\section{Svangerskap, fødsel og barseltid}

Holan S, Hagtvedt ML, red.

Det nye livet

Svangerskap, fødsel, barseltid. 2. utg. 294 s, tab, ill. Bergen: Fagbokforlaget, 2010. Pris NOK 428 ISBN 978-82-450-0671-1

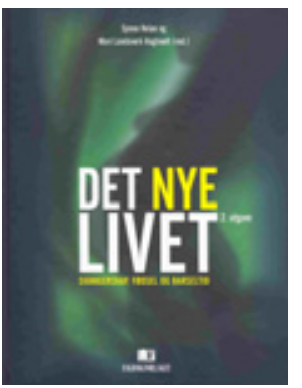

Målgruppen er sykepleiestudenter, men også andre helseprofesjoner som jobber innenfor fagfeltet, og den gravide kvinnen og hennes partner. Boken har 18 bidragsytere, de fleste jordmødre, men man finner også bidrag fra fysioterapeuter, gynekologer, psykiater, psykolog og samfunnsmedisiner. Redaktørene er jordmødre og lektorer ved jordmorutdanningen ved Høyskolen i Vestfold.

Forfatterne ønsker å vektlegge det normale, friske og gledesfylte knyttet til svangerskap, fødsel og barseltid. Samtidig presenteres mangfold og variasjoner og det som kan utgjøre risiko og medføre komplikasjoner for mor og barn. I denne reviderte utgaven har man lagt vekt på kunnskapsbasert praksis.

De 27 kapitlene spenner fra unnfangelse til barseltid. Det er egne kapitler om familieplanlegging, abort og reproduktiv helse $i$ et større perspektiv. Layouten er tiltalende. God bruk av bilder, figurer, illustrasjoner, tabeller og faktabokser gjør boken lettlest og oversiktlig. Det er gode referanser på slutten av hvert kapittel, og her er det også lagt inn relevante nettadresser.

Forfatterne skriver på en enkel og lett tilgjengelig måte. Fremstillingen er varm og engasjerende med fokus på brukerorientering og å legge til rette for egenmestring. Jeg synes også at forfatterne klarer å omtale de mer kontroversielle temaene på en nøktern og balansert måte.

Ved anmeldelsen av førsteutgaven for ti år siden etterlyste jeg en rutinert allmennlege som bidragsyter (1). Boken bærer dessverre preg av manglende kunnskap om denne verdenen, og det er synd etter snart ti år med fastlegeordning og en samhandlingsreform på trappene.

En annen svakhet er at når man leser, kan man få inntrykk av en ressursbruk og behovsdekning i konsultasjonene som ikke er mulig å gjennomføre i praksis, og som heller ikke er rimelig, gitt andre gruppers behov for tid og oppmerksomhet.

Tross mine innvendinger likte jeg boken. Jeg tror at den har mye å gi for sykepleiestudenter, og jeg kommer til å anbefale den til vordende foreldre, som en nøktern kilde til kunnskap i en verden med mye informasjon som er dårlig kvalitetssikret. For leger og medisinstudenter finnes bedre alternativer. De trenger mer faglig ballast, hvor legens rolle er tydeligere.

\section{Bent Folkvord}

Nesttun allmennpraksis

Bergen

\section{Litteratur}

1. Folkvord B. Svangerskap, fødsel og barseltid Anmeldelse av: Holan S, red. Det nye livet. Tidsskr Nor Lægeforen 2000; 120: 2935.

\section{Fanget i eget sinn}

Stene RS.

\section{Den indre smerten}

Din verste fiende? 183 s. Rasta: Forlaget Norske Bøker, 2009. Pris NOK 199

ISBN 978-82-8112-140-9

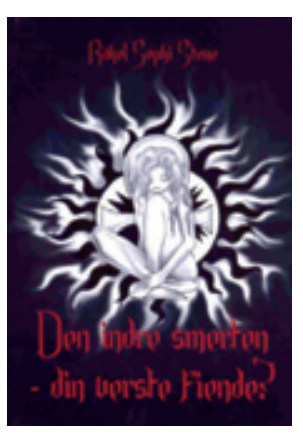

Forfatteren er 23 år gammel og skriver om sine erfaringer etter å ha vært innelukket i sitt eget konfliktfylte sinn gjennom flere år. Sinnet er bebodd av konkrete skikkelser som har fått sine egne navn:

Tvangen, Djevelen, Kontrollen og Hanna. I forfatterens sinn er det full kamp mellom de forskjellige skikkelsene, og den unge jenta føler seg hjelpeløs overfor disse kreftene som har dannet seg i hennes indre. Konteksten er «den jævla angsten for å mislykkes, være alene og være det umulige barnet som bare gjorde ting på faenskap». Disse på en måte fremmede skikkelsene for henne bestemmer mye av hennes handlinger, og «Djevelen inne i meg tryglet om ikke å kjenne på de vonde følelsene». Hennes handlingsrepertoar blir å sulte seg, kaste opp og selvskade seg: «Spyet hadde blitt en veldig god venn som kom opp flere ganger daglig».

Hvordan er det mulig å gjøre så selvdestruktive handlinger som i sin ytterste konsekvens kan være dødelige? Hun forklarer det så vi kan skjønne det: «Man kan ikke drepe en som allerede er død». Gjennom flere år hadde hun følt at hun bare levde fordi hun måtte, og ikke fordi hun kjente seg levende eller opplevde mening. Livet var blitt et ytre tomt skall, og det levende $i$ henne var innelåst uten at hun hadde tilgang til det. Lengselen etter nærhet, kjærlighet og bli forstått var likevel til stede hos henne, men kun i svake uttrykk. Hun beskriver godt hvor avhengig hun var av å bli møtt av omverden på en sensitiv, men likevel direkte måte. Utover i boken forteller hun hvordan terapeuter hjelper henne med å åpne opp for vanskelige følelser og tanker, og gradvis kommer hun seg ut av den indre, låste tilstanden.

Den amerikanske forskeren på borderlinetilstander, Mary Zanarini, beskriver intens, indre smerte som kjerneproblematikken ved disse tilstandene (1). Den indre smerten har både affektive og kognitive aspekter som personen ikke greier å uttrykke $i$ en sosial sammenheng. Teorien om mentaliseringsproblemer som forklaringsmodell for denne typen problematikk, er i dag toneangivende. Man må kunne mentalisere indre tilstander for å legge selvskading, forstyrret spisemønster og liknende handlinger bak seg. Det dreier seg om evnen til å bli klar over og bruke følelsene og forståelsen av egne og andres hensikter i mellommenneskelige situasjoner. Beretningen om en ung jentes kamp i denne sammenhengen er autentisk og vil kunne bidra til økt forståelse og empati for selvdestruktiv atferd, som ikke bare rammer personen selv, men alle $\mathrm{i}$ hennes nære kontekst. Dette gjelder så vel fagpersoner som legfolk.

\section{Øyvind Urnes}

Avdeling for personlighetspsykiatri

Oslo universitetssykehus, Ullevål

Litteratur

1. Zanarini MC, Frankenburg FR. The essential nature of borderline psychopathology. J Pers Disord 2007: 21: 518-35. 